How to cite this paper:

Anuar Hassan, Ahmad Zamzuri M.A., \& Mohd Najib Hamdan (2017). Kesan pelbagai strategi kawalan pengguna animasi bersegmen terhadap prestasi pelajar. Malaysian Journal of Learning and Instruction (MJLI), 14 (2), 293-316.

\title{
KESAN PELBAGAI STRATEGI KAWALAN PENGGUNA ANIMASI BERSEGMEN TERHADAP PRESTASI PELAJAR
}

(EFFECTS OF VARIOUS USER CONTROL STRATEGIES OF SEGMENTED ANIMATION ON STUDENT ACHIEVEMENT)

\section{${ }^{1}$ Anuar Hassan, Ahmad Zamzuri Mohamad Ali \& Mohd Najib Hamdan}

Fakulti Seni, Komputeran \& Industri Kreatif, Universiti Pendidikan Sultan Idris, Malaysia

${ }^{1}$ Corresponding author: anuar5225@gmail.com

\begin{abstract}
ABSTRAK
Tujuan - Kajian ini bertujuan untuk menilai kesan animasi bersegmen dengan pelbagai strategi kawalan pengguna terhadap prestasi pelajar. Lima strategi kawalan tersebut ialah strategi Kawalan Pengguna Linear (KPL), Kawalan Pengguna Rawak (KPR), Kawalan Program (KP), Kawalan Berterusan (KB) dan Tanpa Kawalan (TK).

Metodologi - Reka bentuk kajian berbentuk kuasi eksperimen dan data kajian dianalisis melalui pendekatan kuantitatif. Seramai 265 orang pelajar semester 2 kursus Diploma Sistem Rangkaian dari lima buah Politeknik dipilih sebagai sampel kajian. Penilaian dilakukan melalui ujian pos.

Dapatan - Secara keseluruhan, ujian statistik ANCOVA digunakan untuk menjawab persoalan kajian. Dapatan kajian menunjukkan terdapat perbezaan yang signifikan dari sudut prestasi ujian pos antara
\end{abstract}


kumpulan pelajar yang menerima strategi kawalan paparan animasi bersegmen yang berbeza.

Kepentingan - Dapatan kajian menunjukkan faktor reka bentuk paparan animasi bersegmen yang disertakan dengan strategi kawalan pengguna yang bersesuaian berkemampuan mengatasi masalah keciciran maklumat. Strategi KPR dan KPL didapati membantu dalam memperuntukkan masa yang bersesuaian bagi memori sensori pelajar untuk mengekstrak maklumat bermakna daripada animasi untuk diproses di dalam memori jangka pendek yang agak terbatas sebelum didaftarkan ke dalam memori jangka panjang. Kedua-dua strategi ini juga didapati berupaya meningkatkan prestasi pencapaian pelajar.

Kata kunci: Animasi, kawalan pengguna, kawalan program, segmentasi

\begin{abstract}
Purpose - The aim of this study was to evaluate the effect of segmented animation with various user control strategies on student achievement. The five user control strategies were Linear User Control (KPL), Random User Control (KPR), Program Controlled (KP), Open User Control (KB) and Without Control (TK).

Methodology - The research design was quasi-experimental and the research data were analyzed using a quantitative approach. 265 second semester students pursuing their Diploma in Networking System in five polytechnics were involved in the study. A post test was used to measure the learning outcome.
\end{abstract}

Finding - Overall, the ANCOVA statistical tests indicated significant differences in post test achievements among students who received different control strategies of segmented animation.

Significance - The research findings suggest that segmented animation with appropriate user control strategy is capable of addressing 
information loss limitations. Random user control (KPR) and linear user control (KPL) strategies seem to be useful in allocating appropriate time for students to extract meaningful information from an animation, to be processed in limited short-term memory before it is registered in long-term memory. Both of these strategies are found to capable of improving student achievement.

Keywords: Animation, user controlled, program controlled, segmentation. 


\title{
KESAN PELBAGAI STRATEGI KAWALAN PENGGUNA ANIMASI BERSEGMEN TERHADAP PRESTASI PELAJAR
}

\section{(EFFECTS OF VARIOUS USER CONTROL STRATEGIES OF SEGMENTED ANIMATION ON STUDENT ACHIEVEMENT)}

\author{
${ }^{1}$ Anuar Hassan, Ahmad Zamzuri Mohamad Ali \& \\ Mohd Najib Hamdan \\ Fakulti Seni, Komputeran \& Industri Kreatif, Universiti \\ Pendidikan Sultan Idris, Malaysia
}

${ }^{1}$ Corresponding author: anuar5225@gmail.com

\begin{abstract}
ABSTRAK
Tujuan - Kajian ini bertujuan untuk menilai kesan animasi bersegmen dengan pelbagai strategi kawalan pengguna terhadap prestasi pelajar. Lima strategi kawalan tersebut ialah strategi Kawalan Pengguna Linear (KPL), Kawalan Pengguna Rawak (KPR), Kawalan Program (KP), Kawalan Berterusan (KB) dan Tanpa Kawalan (TK).

Metodologi - Reka bentuk kajian berbentuk kuasi eksperimen dan data kajian dianalisis melalui pendekatan kuantitatif. Seramai 265 orang pelajar semester 2 kursus Diploma Sistem Rangkaian dari lima buah Politeknik dipilih sebagai sampel kajian. Penilaian dilakukan melalui ujian pos.

Dapatan - Secara keseluruhan, ujian statistik ANCOVA digunakan untuk menjawab persoalan kajian. Dapatan kajian menunjukkan terdapat perbezaan yang signifikan dari sudut prestasi ujian pos antara kumpulan pelajar yang menerima strategi kawalan paparan animasi bersegmen yang berbeza.
\end{abstract}

Kepentingan - Dapatan kajian menunjukkan faktor reka bentuk paparan animasi bersegmen yang disertakan dengan strategi kawalan 
pengguna yang bersesuaian berkemampuan mengatasi masalah keciciran maklumat. Strategi KPR dan KPL didapati membantu dalam memperuntukkan masa yang bersesuaian bagi memori sensori pelajar untuk mengekstrak maklumat bermakna daripada animasi untuk diproses di dalam memori jangka pendek yang agak terbatas sebelum didaftarkan ke dalam memori jangka panjang. Kedua-dua strategi ini juga didapati berupaya meningkatkan prestasi pencapaian pelajar.

Kata kunci: Animasi, kawalan pengguna, kawalan program, segmentasi

\section{ABSTRACT}

Purpose - The aim of this study was to evaluate the effect of segmented animation with various user control strategies on student achievement. The five user control strategies were Linear User Control (KPL), Random User Control (KPR), Program Controlled (KP), Open User Control (KB) and Without Control (TK).

Methodology - The research design was quasi-experimental and the research data were analyzed using a quantitative approach. 265 second semester students pursuing their Diploma in Networking System in five polytechnics were involved in the study. A post test was used to measure the learning outcome.

Finding - Overall, the ANCOVA statistical tests indicated significant differences in post test achievements among students who received different control strategies of segmented animation.

Significance - The research findings suggest that segmented animation with appropriate user control strategy is capable of addressing information loss limitations. Random user control (KPR) and linear user control (KPL) strategies seem to be useful in allocating appropriate time for students to extract meaningful information from an animation, to be processed in limited short-term memory before it is registered in long-term memory. Both of these strategies are found to capable of improving student achievement.

Keywords: Animation, user controlled, program controlled, segmentation. 


\section{PENGENALAN}

Animasi dilihat mempunyai banyak kelebihan dan disokong oleh teori namun dapatan kajian terhadap keberkesanan animasi dalam pembelajaran adalah tidak konsisten (Lin \& Dwyer, 2010; Ayres, Marcus, Chan \& Qian, 2009; Ainsworth, 2008; Hegarty, 2004; Lin \& Dwyer, 2004; Sperling, Seyedmonir, Aleksic \& Meadows, 2003). Punca utama dapatan kajian yang tidak konsisten adalah disebabkan kelemahan dari sudut reka bentuk (Spanjers, Van Gog, \& van Merrienboer, 2010; Tversky, Morrison \& Betrancourt, 2002; Liu, Jones \& Hemstreet, 1998) dan perbezaan ciri pembelajaran pelajar, seperti keupayaan visualisasi, cara belajar, motivasi, pengetahuan sedia ada, umur, jantina dan sebagainya (Spanjers, van Gog \& van Merrienboer, 2010; Mayer \& Moreno, 2002).

Dari sudut reka bentuk, ciri animasi yang berubah mengikut masa akan menyebabkan pelajar terkeliru dan bercelaru sepanjang proses melihat paparan animasi tersebut. Ini disebabkan mereka tidak berupaya memproses jujukan maklumat bertali arus dalam sistem memori, kerana kapasiti maklumat yang diterima dalam satu-satu masa adalah sangat terhad (Wong, Leahy, Marcus \& Sweller, 2012; Ayres, Marcus, Chan \& Qian, 2009; Van Oostendrop, Beijersbergen \& Solaimani, 2008). Hal ini juga berpotensi mengakibatkan fokus dan perhatian pelajar tidak dapat ditumpukan terhadap maklumat penting dalam sesuatu persembahan animasi (Wilson \& Dwyer, 2001). Oleh itu, reka bentuk animasi yang tidak memperuntukkan tempoh masa yang bersesuaian bagi pelajar untuk menumpukan perhatian terhadap maklumat yang dipersembahkan, merupakan antara faktor kegagalan animasi dalam membantu pembelajaran berkesan (Torres \& Dwyer, 1991). Storan memori manusia adalah terbahagi kepada tiga komponen utama iaitu memori sensori, memori jangka pendek dan memori jangka panjang (Atkinson \& Shiffrin, 1968). Maklumat kebiasaannya disimpan di dalam memori sensori sekitar $1 / 2$ hingga 1 saat manakala memori jangka pendek pula akan menyimpan maklumat sekitar 5 hingga 15 saat (Atkinson \& Shiffrin, 1968). Maklumat pertama yang memasuki memori sensori akan disimpan dalam tempoh masa tersebut sebelum maklumat berikutnya diterima Tanpa peruntukan masa yang bersesuaian, pelajar akan gagal membina model mental yang sempurna dalam struktur memori (Mireille \& Cyril, 2007). Menurut Norman (1982) pula, maklumat pertama ini akan luput secara eksponen daripada 
memori ini iaitu sebanyak 1/3 bagi setiap 100-150 mili saat. Batasan tempoh masa ini akan menyebabkan tidak semua maklumat akan berjaya memasuki storan memori jangka panjang untuk didaftarkan secara kekal di dalamnya (Clark, Nguyen \& Sweller, 2011; JunXia, 2007; Sweller,2004). Kebanyakan aplikasi animasi bagi tujuan instruksi mungkin kurang berkesan kerana pereka bentuk bahan instruksi gagal mengambil kira cabaran pemprosesan maklumat ini terhadap pelajar dalam reka bentuk mereka (Lowe, 2004).

Animasi yang disegmenkan dengan strategi kawalan yang mengawal paparan segmen-segmen tersebut, berbanding melihat keseluruhan paparan animasi secara berterusan secara pasif boleh dijadikan antara penyelesaian dalam menangani permasalahan ini (Moreno, 2007; Mayer \& Moreno, 2003; Mayer \& Chandler, 2001). Dapatan kajian juga menunjukkan, animasi yang disegmenkan akan memperuntukkan tempoh masa yang bersesuaian untuk pelajar menginterpretasikan dan memahami animasi secara lebih berkesan (Ahmad Zamzuri, 2013; 2007; Aminordin, Ng \& Fong, 2004; Fong, 2001). Namun, bagi memastikan keberkesanan maksimum pembelajaran, pemilihan strategi kawalan animasi bersegmen yang betul adalah penting dipertimbangkan (Spanjers, Van Gog \& Van Merrienboer, 2010; Ahmad Zamzuri, 2007). Terdapat banyak kajian lampau berkaitan animasi dalam pembelajaran, namun tidak banyak kajian yang ditumpukan terhadap strategi kawalan terhadap animasi bersegmen (Lai, 2001). Antara kajian-kajian lampau yang berkaitan keberkesanan strategi kawalan animasi terhadap pembelajaran ialah Kajian oleh Moreno (2007) ke atas sekumpulan 143 orang guru pelatih telah berjaya membuktikan keberkesanan animasi bersegmen dalam pengajaran, kajian oleh Mayer et al., (2003) terhadap topik fungsi motor elektrik yang dipersembahkan dalam bentuk animasi serta diikuti oleh kajian Boucheix dan Scheneider (2009) berkaitan pembelajaran Topik sistem takal (Three Pulley System) yang menggunakan tiga kaedah strategi paparan animasi. Secara umumnya, terdapat dua strategi kawalan yang boleh digunakan dalam memaparkan animasi bersegmen, iaitu kawalan pengguna dan kawalan program (Spanjers, van Gog \& van Merrienboer, 2010; Lai, 2001).

Fitur kawalan pengguna adalah suatu strategi yang boleh diaplikasikan dalam reka bentuk supaya pelajar dapat memperuntukkan masa yang bersesuaian untuk mengamati isi kandungan yang disampaikan (Alessi \& Trollip, 2001). Dengan menggunakan aplikasi kawalan 
pengguna, pelajar boleh mengamati satu segmen dan bergerak ke segmen berikutnya apabila telah bersedia (Wouters, Paas \& van Merrienboer, 2004). Namun, kawalan pengguna mempunyai implikasi mencapah perhatian (split attention) pelajar terhadap operasi kawalan berbanding isi pelajaran (Boucheix \& Schneider, 2009). Hal ini juga mampu meningkatkan bebanan kognitif pelajar sepanjang proses pembelajaran dan menyebabkan maklumat sukar didaftar secara kekal dalam struktur memori (Sweller \& Chandler, 1994).

Sebagai alternatif, fitur kawalan program mungkin boleh digunakan bagi menangani masalah ini. Dengan menggunakan aplikasi kawalan program, pelajar boleh mengamati segmen-segmen dan pergerakan antara segmen secara linear adalah ditentukan oleh pembangun animasi (Spanjers, van Gog \& van Merrienboer, 2010; Lai, 2001). Dengan kaedah ini, pelajar tidak perlu memberi tumpuan terhadap fitur kawalan dan mereka dapat memberi sepenuh perhatian terhadap pembelajaran. Walau bagaimanapun persoalan timbul dari sudut tempoh masa sesuai pergerakan dari satu segmen ke segmen yang lain secara linear, kerana kemampuan pelajar tidak semuanya sama. Tempoh masa yang terlalu cepat akan menyebabkan pelajar tidak mampu mengekstrak sebarang maklumat relevan daripada paparan statik antara segmen, manakala tempoh masa yang terlalu lama pula akan menyebabkan kebosanan dan keletihan yang akan mengurangkan tumpuan dan menyebabkan kegagalan pembelajaran (Weir \& Heeps, 2004).

Paparan secara linear segmen animasi dalam kawalan pengguna atau kawalan program juga mempunyai implikasi lain, seperti berpotensi meningkatkan kebosanan pelajar. Persoalan timbul, adakah pelajar yang telah memahami satu segmen masih berminat untuk mengulanginya dalam proses untuk memahami setiap segmen dalam sesuatu animasi? Sehubungan itu, kawalan pengguna yang memberi kebebasan navigasi bagi pelajar untuk memilih sendiri segmen untuk dipapar dilihat dapat menangani masalah ini (Tabbers $\&$ de Koeijer, 2009; Betrancourt, 2005). Dengan kebebasan navigasi, pelajar boleh memberi tumpuan sepenuhnya terhadap kandungan yang mereka berminat atau masih belum mahir (Cairncross \& Mannion, 2001). Sehubungan itu, kebosanan dapat dielakkan kerana pelajar boleh melangkau kandungan yang telah mereka fahami dan mengelak kandungan yang mereka belum bersedia untuk pelajari (Li \& Soh, 2003). Namun, memberi kebebasan penuh kepada 
pelajar untuk mengawal paparan segmen animasi tidak semestinya membawa hasil positif pembelajaran (Boucheix \& Schneider, 2009; Ahmad Zamzuri, 2007) dan ianya juga mempunyai implikasi pelajar melangkau maklumat (Schnackenberg \& Sullivan, 2000). Malahan pula, terdapat juga kajian yang mendapati pelajar novis tidak mempunyai pengetahuan untuk mengenal pasti bahagian paling relevan animasi untuk dipelajari serta mereka tidak menggunakan kebebasan kawalan secara efektif (Lowe, 2003; Kettanurak, Ramamurthy \& Haseman, 2001). Walaubagaimana pun, reka bentuk paparan animasi bersegmen yang disertakan dengan ciri kawalan pengguna samaada secara linear atau rawak dilihat mampu untuk membantu meningkatkan pemahaman pelajar ketika proses pembelajaran berlangsung. Sehubungan itu, penyelidikan ini adalah bertujuan untuk melihat kesan reka bentuk pelbagai strategi kawalan paparan animasi bersegmen terhadap prestasi pelajar. Lima strategi kawalan paparan animasi bersegmen yang dibangunkan dan diuji ialah Animasi Kawalan Pengguna Linear (KPL), Kawalan Pengguna Rawak (KPR), Kawalan Program (KP), Kawalan Pengguna Bebas (KB) dan Tanpa Kawalan (TK). Kelima-lima strategi ini merupakan antara jenis strategi yang telah digariskan oleh Mayer (2001) sebagai prinsip asas kawalan navigasi dalam pembangunan aplikasi multimedia untuk pembelajaran.

\section{METODOLOGI}

\section{Objektif kajian}

Kajian yang dijalankan ini bertujuan untuk melihat kesan lima strategi kawalan paparan segmen animasi iaitu Kawalan Pengguna Linear (KPL), Kawalan Pengguna Rawak (KPR), Kawalan Berterusan (KB), Kawalan Program (KP) dan Tanpa Kawalan (TK) terhadap prestasi ujian pos pelajar politeknik. Secara terperinci, objektif kajian adalah seperti berikut:

a) Mengenal pasti perbezaan prestasi ujian pos di antara kumpulan pelajar yang menerima strategi kawalan paparan segmen animasi KPL, KPR, KB, KP dan TK.

\section{Media Instruksi}

Pembangunan prototaip koswer animasi bersegmen adalah mengikuti prinsip-prinsip reka bentuk multimedia instruksi. Model DDD-E 
yang dibangunkan oleh Ivers dan Barron pada tahun 1998 telah dijadikan asas strategi pembangunan. Model DDD-E mempunyai 4 akronim yang mewakili setiap satu fasa iaitu fasa Decide, Design, Develop dan Evaluate. Justifikasi model ini dipilih ialah kerana ciricirinya yang merangkumi fasa-fasa asas pembangunan iaitu analisis, reka bentuk, pembangunan dan perlaksanaan. Manakala penilaian secara berterusan membolehkan koswer yang dibangunkan melalui model DDD-E ini boleh dinilai dan dibaiki dari semasa ke semasa. Secara ringkasnya, perbezaan antara kelima-lima animasi bersegmen ialah daripada aspek strategi kawalan pengguna yang digunakan seperti berikut:

a) Strategi Kawalan Pengguna Linear (KPL)

Animasi dibahagikan kepada beberapa segmen yang bermakna. Pelajar boleh mara atau undur dari satu segmen ke segmen yang lain mengikut kehendak mereka dengan menekan butang mara dan undur yang disediakan. Pelajar hanya boleh mara dan undur secara turutan linear dari satu segmen ke segmen yang lain.

\section{(1) 125450}

Rajah 1. Navigasi strategi KPL

b) Strategi Kawalan Pengguna Rawak (KPR)

Animasi dibahagikan kepada beberapa segmen yang bermakna. Pelajar boleh melihat mana-mana segmen animasi mengikut kehendak mereka dengan menekan butang segmen berkaitan. Pemilihan segmen adalah secara rawak mengikut kehendak pelajar.

1234567891011121314151617181920

Rajah 2. Navigasi strategi KPR 
c) Strategi Kawalan Program (KP)

Animasi dibahagikan kepada beberapa segmen yang bermakna. Pergerakan dari satu segmen ke segmen yang lain adalah ditentukan oleh pembangun animasi. Paparan segmen animasi adalah dikawal sepenuhnya oleh komputer. Keseluruhan paparan segmen animasi adalah secara linear dengan sela masa tertentu antara setiap segmen tersebut. Pelajar boleh mengulang tayang paparan segmen-segmen animasi berulang kali dengan menekan butang ulang.

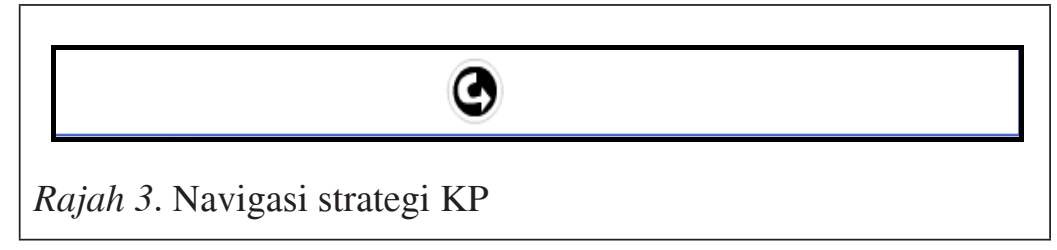

d) Strategi Kawalan Berterusan (KB)

Animasi akan dipaparkan secara berterusan dari mula sehingga tamat apabila pelajar menekan butang mula. Pelajar boleh menghentikan animasi di mana-mana bahagian dengan menekan butang berhenti dan memainkan semula dengan menekan butang terus.

\section{OO9}

Rajah 4. Navigasi letak strategi KB

e) Strategi Tanpa Kawalan (TK)

Animasi akan dipaparkan secara berterusan dari mula hingga tamat apabila pelajar menekan butang mula. Pelajar boleh mengulang paparan animasi dengan menekan butang ulang.

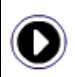

Rajah 5. Navigasi strategi TK 


\section{Sampel kajian}

Sampel bagi kajian ini terdiri daripada pelajar-pelajar semester dua program Diploma Sistem Rangkaian dari lima buah politeknik yang dipilih secara persampelan berperingkat (Creswell, 2012). Dua kelas dari program Diploma Sistem Rangkaian semester dua dipilih dari setiap politeknik. Penentuan kelas dilakukan oleh pihak pengurusan Jabatan Teknologi Maklumat dan Komputer politeknik masingmasing. Sehubungan itu, seramai 265 orang pelajar telah diambil sebagai sampel kajian.

\section{Prosedur Kajian}

Kajian ini berbentuk kuasi eksperimen dan dijalankan di lima buah politeknik di bawah Kementerian Pelajaran Malaysia (KPM). Politeknik yang dikenal pasti ialah Politeknik Tuanku Syed Sirajuddin (PTSS), Arau, Perlis, Politeknik Mukah (PMU), Sarawak, Politeknik Mersing Johor (PMJ), Mersing, Johor, Politeknik Kuching (PKU), Sarawak dan Politeknik Muadzam Shah (PMS), Kuantan, Pahang. Kelima-lima politeknik ini menawarkan kursus Diploma Sistem Rangkaian. Kesemua politeknik yang dipilih ini terdiri dari kelompok politeknik konvensional dan dipilih secara pensampelan berperingkat (Creswell, 2012). Sampel kajian pula terdiri daripada pelajar-pelajar semester dua program Diploma Sistem Rangkaian dari setiap politeknik yang dipilih. Dua kelas dari program Diploma Sistem Rangkaian semester dua dipilih dari setiap politeknik. Penentuan kelas dilakukan oleh pihak pengurusan Jabatan Teknologi Maklumat dan Komputer politeknik masingmasing. Tiada kriteria pemilihan kelas yang spesifik memandangkan enrolmen untuk program ini adalah sekitar 55- 60 orang pelajar sahaja untuk setiap politeknik. Unjuran enrolmen ini adalah mencukupi untuk dua kelas sahaja. Seramai dua orang pensyarah pembantu dilantik sebagai pengawas ketika sesi ujian saringan awal, ujian pra dan ujian pos. Taklimat tentang penggunaan koswer dan peraturan mengawas diberikan kepada pensyarah pembantu sebelum proses kajian dimulakan. Ujian pra dilaksanakan dengan tujuan untuk mengetahui tahap kesetaraan pengetahuan pelajar terhadap topik yang diuji. Ujian ini mengandungi 9 soalan isi tempat kosong dan 2 soalan berbentuk esei respons terhad. Tempoh masa menjawab ialah 40 minit. Aras soalan adalah terdiri dari gabungan aras rendah, sederhana dan tinggi berdasarkan taksonomi Bloom. 
Selepas ujian pra, koswer Troubleshooting the Network dibekalkan kepada setiap individu pelajar di dalam makmal komputer dengan kemudahan sebuah komputer untuk seorang pelajar. Pensyarah pembantu mengambil sedikit masa untuk memberi penerangan tentang panduan penggunaan koswer tersebut kepada semua pelajar secara serentak. Sejurus selesai sesi penerangan tersebut, pelajar memulakan sesi pembelajaran kendiri selama 40 minit di makmal tersebut. Ujian pos dilaksanakan sebaik sahaja pelajar selesai aktiviti pembelajaran. Kriteria pemilihan kumpulan pelajar untuk setiap strategi kawalan adalah secara rawak mengikut kedudukan zon politeknik. Jadual 1 dibawah menunjukan pecahan kumpulan terhadap strategi kawalan yang digunakan.

Jadual 1

Pecahan kumpulan terhadap jenis strategi yang digunakan

\begin{tabular}{ccc}
\hline Politeknik & Bilangan Sampel & Strategi Kawalan \\
\hline PTSS & 49 & KPR \\
PMJ & 53 & KPL \\
PMS & 51 & KP \\
PMU & 57 & KB \\
PKU & 55 & TK \\
\hline
\end{tabular}

\section{Instrumen Kajian}

Instumen digunakan dalam kajian ini ialah ujian pra dan ujian pos Kedua ujian ini adalah berbentuk konvensional, iaitu menggunakan kaedah kertas dan pen. Ujian-ujian ini bertujuan untuk menguji dan menentukan tahap kefahaman tentang konsep-konsep abstrak yang terdapat di dalam koswer modul Network Fundamental. Antara perkara abstrak yang diuji dalam siri ujian ini ialah proses perubahan protokol ketika komunikasi dua hala sedang berlaku. Perubahan dan transisi protokol akan digambarkan dalam koswer animasi yang telah dibangunkan.

Ujian pra dan ujian pos adalah sama dari segi kandungan dan bilangan soalan. Namun begitu, susunan dan olahan soalan dalam kedua-dua ujian itu adalah berbeza. Kedua-dua set soalan itu mengandungi dua bahagian, iaitu Bahagian A dan Bahagian B. 
Bahagian A mengandungi 9 soalan isi tempat kosong dan bahagian B mengandungi 2 soalan esei respons terhad. Set soalan ujian pra dan pos ini melalui proses pra uji sebelum pengujian sebenar. Pelajar diperuntukkan masa selama 40 minit untuk menerokai koswer dan 40 minit untuk menjawab kesemua soalan. Kertas jawapan ini disemak oleh tiga orang pemeriksa berdasarkan skema yang disediakan.

\section{ANALISIS DATA}

Secara keseluruhan, analisis ANCOVA telah digunakan untuk menguji sama ada wujud sebarang perbezaan signifikan terhadap prestasi ujian pos antara kumpulan pelajar yang menerima pelbagai strategi kawalan paparan animasi bersegmen. Manakala, kovariat yang digunakan untuk menjawab persoalan kajian ini ialah ujian pra. Sebelum itu, beberapa syarat didapati telah dipenuhi bagi memastikan data kajian boleh digunakan untuk menjawab persoalan kajian pertama ini menggunakan analisis ANCOVA. Rumusan dapatan analisis pada Jadual 2, selepas pelarasan (adjusted), skor ujian pos menunjukkan terdapat perbezaan yang signifikan dari sudut pencapaian ujian pos pelajar berdasarkan strategi kawalan paparan segmen animasi KPL, KPR, KB, KP dan TK, F (4, 259) $=5.99, \mathrm{p}<0.05$, partial eta Kuasa dua $=0.09$, dengan kesan saiz dalam lingkungan antara sederhana dan tinggi mengikut garis panduan Cohen 1998 (Pallant, 2007).

\section{Jadual 2}

Keputusan ujian ANCOVA bagi skor ujian pos berdasarkan strategi kawalan animasi bersegmen dan skor min ujian pra sebagai kovariat

Pembolehubah bersandar : Purata ujian pos

\begin{tabular}{ccccccc}
\hline & $\begin{array}{c}\text { Jumlah Kuasa } \\
\text { dua Jenis III }\end{array}$ & Dk & Dua & F & Sig. & Dua \\
\hline Corrected Model & 4515.11 & 5 & 903.02 & 6.65 & .000 & .11 \\
Intercept & 117272.55 & 1 & 117272.55 & 864.03 & .000 & .77 \\
UJIAN_PRA & 2170.38 & 1 & 2170.38 & 15.99 & .000 & .06 \\
KUMPULAN & 3252.74 & 4 & 813.19 & 5.99 & .000 & .09 \\
Error & 35153.52 & 259 & 135.73 & & & \\
Total & 1101811.00 & 265 & & & & \\
Corrected Total & 39668.63 & 264 & & & & \\
\hline
\end{tabular}


a. $\quad$ R Kuasa Dua $=.11($ Kuasa Dua Selepas Pelarasan $=.10)$

Perincian keputusan analisis pada Jadual 3 pula menunjukkan strategi kawalan animasi bersegmen jenis KPR memperoleh prestasi yang terbaik selepas pelarasan skor ujian pos, $(M=67.75$, $\mathrm{SE}=1.56)$ diikuti $\mathrm{KPL}(\mathrm{M}=67.33, \mathrm{SE}=1.67), \mathrm{KP}(\mathrm{M}=61.76$, $\mathrm{SE}=1.57)$ dan $\mathrm{KB}(\mathrm{M}=60.71, \mathrm{SE}=1.57)$ dan $\mathrm{TK}(\mathrm{M}=58.86, \mathrm{SE}$ $=1.67)$.

Jadual 3

Rumusan analisis deskriptif skor min ujian pos yang belum di selaraskan dan telah diselaraskan mengikut urutan tertinggi

\begin{tabular}{|c|c|c|c|c|c|}
\hline \multirow{2}{*}{$\begin{array}{l}\text { Kumpulan } \\
\text { Strategi } \\
\text { Animasi } \\
\text { Kawalan }\end{array}$} & \multirow[b]{2}{*}{$\mathrm{N}$} & \multicolumn{2}{|c|}{$\begin{array}{l}\text { Min Belum } \\
\text { diselaraskan } \\
\text { (unadusjted) }\end{array}$} & \multicolumn{2}{|c|}{$\begin{array}{l}\text { Min Telah } \\
\text { diselaraskan } \\
\text { (adjusted) }\end{array}$} \\
\hline & & Min & $\begin{array}{l}\text { Sisihan } \\
\text { Piawai }\end{array}$ & Min & $\begin{array}{l}\text { Sisihan } \\
\text { Ralat }\end{array}$ \\
\hline KPR & 57 & 67.88 & 1.82 & 67.75 & 1.56 \\
\hline KPL & 49 & 67.28 & 1.68 & 67.33 & 1.67 \\
\hline $\mathrm{KP}$ & 55 & 61.75 & 1.59 & 61.76 & 1.57 \\
\hline $\mathrm{KB}$ & 53 & 60.58 & 1.62 & 60.71 & 1.60 \\
\hline TK & 51 & 58.33 & 1.79 & 58.86 & 1.67 \\
\hline
\end{tabular}

Sementara itu, ujian Post-Hoc Bonferonni telah dilaksanakan untuk mengenal pasti kumpulan strategi pembelajaran yang menunjukkan perbezaan yang signifikan berbanding kumpulan-kumpulan lain. Ujian ini menggunakan skor min ujian pos yang telah diselaraskan (adjusted). Rujuk Jadual 4 untuk ulasan perbandingan. Dapatan dari ujian ini menunjukkan terdapat perbezaan yang signifikan di antara kumpulan pelajar yang menerima pembelajaran menggunakan strategi kawalan animasi bersegmen jenis KPL dan KB $(\mathrm{MD}=$ $6.62, \mathrm{p}<0.05)$. Berdasarkan perbezaan skor min ujian pos bagi kumpulan pelajar yang yang menggunakan kawalan animasi bersegmen jenis KPL $(\mathrm{M}=67.33)$ adalah lebih baik berbanding pencapaian kumpulan yang menerima strategi pembelajaran KB 
$(\mathrm{M}=60.71)$. Maka dengan itu didapati KPL adalah lebih baik dari sudut peningkatan pencapaian berbanding pelajar KB.

Bagi dapatan ujian KPL dan TK pula, wujud perbezaan yang signifikan di antara kumpulan pelajar yang menerima pembelajaran menggunakan strategi kawalan animasi bersegmen jenis KPL dan TK $(\mathrm{MD}=8.48, \mathrm{p}<0.05)$. Berdasarkan perbezaan min ujian pos bagi kumpulan pelajar yang menggunakan kawalan animasi bersegmen jenis KPL $(M=67.33)$ adalah lebih baik berbanding pencapaian kumpulan yang menerima strategi pembelajaran TK (M =58.86). Maka dengan itu didapati KPL adalah lebih baik dari sudut peningkatan pencapaian berbanding pelajar TK.

Perbandingan dapatan ujian KPR dan KB juga wujud perbezaan yang signifikan di antara kumpulan pelajar yang menerima pembelajaran menggunakan strategi kawalan animasi bersegmen jenis tersebut $(\mathrm{MD}=7.04, \mathrm{p}<0.05)$. Berdasarkan perbezaan min ujian pos bagi mendapati kumpulan pelajar yang menggunakan kawalan animasi bersegmen jenis KPR $(\mathrm{M}=67.75)$ adalah lebih baik berbanding pencapaian kumpulan menerima strategi pembelajaran $\mathrm{KB}(\mathrm{M}=$ 60.71). Maka dengan itu didapati KPR adalah lebih baik dari sudut peningkatan pencapaian berbanding pelajar KB.

Jenis Strategi kawalan animasi bersegmen KPR juga mempunyai perbezaan yang signifikan dengan jenis TK. Nilai perbezaan tersebut ialah $(\mathrm{MD}=8.89, \mathrm{p}<0.05)$. Berdasarkan perbezaan min ujian pos bagi mendapati kumpulan pelajar yang berbeza tahap pengetahuan sedia ada yang menggunakan kawalan animasi bersegmen jenis KPR $(\mathrm{M}=67.75)$ adalah lebih baik berbanding pencapaian kumpulan menerima strategi pembelajaran TK $(\mathrm{M}=58.86)$. Maka dengan itu didapati KPR adalah lebih baik dari sudut peningkatan pencapaian berbanding pelajar TK.

Dapatan dari ujian Post-Hoc Bonferonni juga menunjukkan tidak terdapat perbezaan yang signifikan di antara kumpulan pelajar menerima pembelajaran menggunakan strategi pembelajaran KP dengan pasangan KPL $(\mathrm{MD}=5.58, \mathrm{p}>0.05)$, KPR $(\mathrm{MD}=5.10, \mathrm{p}$ $>0.05)$, KB $(\mathrm{MD}=1.05, \mathrm{p}>0.05)$ dan TK $(\mathrm{MD}=2.90, \mathrm{p}>0.05)$. Ini menunjukkan tiada perbezaan signifikan dari sudut pencapaian pelajar. 
Jadual 4

Dapatan ujian Post-Hoc Bonferonni untuk skor ujian pos

Pembolehubah bersandar : Purata skor min ujian pos

\begin{tabular}{|c|c|c|c|c|c|c|}
\hline \multirow[b]{2}{*}{ (I) KUMPULAN } & \multirow[b]{2}{*}{ (J) KUMPULAN } & \multirow{2}{*}{$\begin{array}{c}\text { Perbezaan Min } \\
\text { (I-J) }\end{array}$} & \multirow{2}{*}{$\begin{array}{l}\text { Ralat } \\
\text { Piawai }\end{array}$} & \multirow[b]{2}{*}{ Sig. ${ }^{a}$} & \multicolumn{2}{|c|}{ 95\% Aras Keyakinan } \\
\hline & & & & & $\begin{array}{c}\text { Had } \\
\text { Bawah }\end{array}$ & Had Atas \\
\hline \multirow[t]{4}{*}{ KPL } & KPR & -.42 & 2.28 & 1.00 & -6.86 & 6.03 \\
\hline & KB & 6.62 & 2.31 & .04 & .09 & 13.16 \\
\hline & KP & 5.58 & 2.30 & .16 & -.92 & 12.07 \\
\hline & TK & 8.48 & 2.37 & .00 & 1.77 & 15.19 \\
\hline \multirow[t]{4}{*}{ KPR } & KPL & .42 & 2.28 & 1.000 & -6.03 & 6.86 \\
\hline & $\mathrm{KB}$ & 7.04 & 2.23 & .02 & .73 & 13.35 \\
\hline & $\mathrm{KP}$ & 5.10 & 2.23 & .08 & -.31 & 12.30 \\
\hline & TK & 8.89 & 2.33 & .00 & 2.31 & 15.48 \\
\hline \multirow[t]{4}{*}{$\mathrm{KB}$} & KPL & -6.62 & 2.31 & .04 & -13.16 & -.09 \\
\hline & KPR & -7.04 & 2.23 & .02 & -13.35 & -.73 \\
\hline & KP & -1.05 & 2.25 & 1.00 & -7.41 & 5.32 \\
\hline & TK & 1.85 & 2.33 & 1.00 & -4.73 & 8.44 \\
\hline \multirow[t]{4}{*}{$\mathrm{KP}$} & KPL & -5.58 & 2.29 & .16 & -12.07 & .92 \\
\hline & KPR & -5.10 & 2.23 & .08 & -12.30 & .31 \\
\hline & $\mathrm{KB}$ & 1.05 & 2.25 & 1.00 & -5.32 & 7.41 \\
\hline & TK & 2.90 & 2.28 & 1.00 & -3.56 & 9.36 \\
\hline \multirow[t]{4}{*}{ TK } & KPL & -8.48 & 2.37 & .00 & -15.19 & -1.77 \\
\hline & KPR & -8.90 & 2.33 & .00 & -15.48 & -2.31 \\
\hline & $\mathrm{KB}$ & -1.85 & 2.33 & 1.00 & -8.44 & 4.73 \\
\hline & KP & -2.90 & 2.28 & 1.00 & -9.36 & 3.56 \\
\hline
\end{tabular}

\section{PERBINCANGAN}

Dapatan kajian secara keseluruhan menunjukkan wujud perbezaan signifikan dari sudut prestasi ujian pos antara kumpulan pelajar yang menggunakan animasi bersegmen dengan strategi kawalan yang berbeza. Berdasarkan dapatan ujian perbandingan pasangan, tidak ada perbezaan signifikan terhadap prestasi kumpulan pelajar yang mengikuti strategi KPR, KPL dan KP. Manakala prestasi kumpulan 
pelajar yang mengikuti strategi KPR, KPL dan KP didapati adalah lebih baik berbanding strategi KB dan TK. Namun, secara statistik, tidak wujud sebarang perbezaan signifikan antara strategi KP, KB dan TK. Dapatan ini menunjukkan animasi yang disegmen dengan disertakan kawalan pengguna, sama ada secara linear atau rawak adalah lebih membantu pembelajaran berbanding animasi paparan berterusan. Hal ini adalah disebabkan oleh faktor reka bentuk paparan animasi yang membenarkan tempoh masa selama 15 saat pada setiap segmen yang dipaparkan. Tempoh ini dilihat begitu signifikan untuk jenis pembelajaran dan pengajaran topik-topik abstrak. Dapatan ini dilihat selari dengan kajian Moreno (2007) yang menyimpulkan bahawa animasi bersegmen dengan kawalan pengguna linear adalah lebih baik berbanding animasi paparan berterusan. Dapatan kajian Ahmad Zamzuri (2007) juga menegaskan bahawa animasi bersegmen dengan strategi kawalan pengguna linear, memberi kesan pencapaian yang lebih baik berbanding strategi kawalan bebas dan strategi tanpa kawalan. Manakala kajian oleh Mayer et al. (2003) juga membuktikan keberkesanan animasi bersegmen dengan strategi kawalan linear berbanding animasi paparan berterusan tanpa kawalan. Spanjers, van Gog dan van Merrienboer (2010) turut merumuskan secara statistik bahawa animasi bersegmen dengan strategi kawalan pengguna secara linear adalah lebih baik dari sudut peningkatan prestasi pencapaian pelajar berbanding animasi paparan berterusan tanpa kawalan. Walaupun kajian-kajian ini hanya terbatas terhadap membandingkan animasi bersegmen dengan animasi paparan berterusan, namun ianya jelas menunjukkan bahawa animasi bersegmen yang dipapar secara linear dengan sebarang kawalan pengguna adalah tetap lebih baik berbanding animasi paparan berterusan.

Secara terperinci, strategi KPR ialah strategi kawalan yang membolehkan pelajar melihat segmen animasi secara linear atau mana-mana segmen animasi secara rawak mengikut keperluan dengan menekan butang segmen berkaitan. Manakala strategi KPL pula hanya membenarkan pelajar mara atau undur secara linear dari satu segmen ke segmen yang lain mengikut kehendak mereka dengan menekan butang mara dan undur yang disediakan. Strategi KP adalah sama dengan strategi KPL tetapi sela masa berhenti antara segmen dengan pergerakan secara linear adalah ditentukan oleh pembangun perisian. Persamaan yang ada dalam ketiga-tiga strategi ini merupakan pergerakan dari satu segmen ke segmen yang 
lain adalah secara linear. Pergerakan secara linear dilihat mendorong pelajar menerokai keseluruhan kandungan animasi secara sistematik tanpa melangkau maklumat pembelajaran yang berada dalam setiap segmen animasi. Walaupun dalam strategi KPR, selain pergerakan secara linear pelajar juga diperuntukkan kebebasan dalam memilih segmen secara rawak, namun kebebasan ini tidak menunjukkan sebarang kelebihan tambahan terhadap pembelajaran. Sehubungan itu, timbul persoalan, adakah pelajar benar-benar memanfaatkan fitur tambahan yang ada dalam strategi ini sepanjang proses pembelajaran? Faktor topik yang abstrak mungkin tidak menggalakkan pelajar menggunakan fitur ini sepanjang proses pembelajaran. Kajian lanjutan yang melihat interaksi pelajar terhadap fitur kawalan dilihat adalah perlu bagi menjawab persoalan ini, terutamanya bagi pembelajaran topik yang abstrak.

Animasi yang di segmenkan serta dipapar secara linear dilihat mempunyai kelebihan dari sudut membolehkan pelajar memperuntukkan tempoh masa yang bersesuaian bagi mengekstrak serta menginterpretasikan maklumat-maklumat berguna sepanjang proses pembelajaran, terutamanya dalam pembelajaran topik-topik yang berbentuk abstrak (Ahmad Zamzuri, 2013; Hasler, Kersten \& Sweller, 2007; Alessi \& Trollip, 2001). Hal ini, berpotensi mengatasi masalah keciciran maklumat bagi membantu pembentukan model mental yang sempurna dalam memori kerja untuk pembelajaran berkesan. Animasi bersegmen juga dilihat membantu menggalakkan pemprosesan aktif dan pasif dalam struktur memori pelajar. Di mana, pemprosesan aktif berlaku sepanjang persembahan animasi di dalam sesuatu segmen manakala pemprosesan pasif berlaku apabila animasi berhenti seketika sebelum ke segmen yang seterusnya. Gabungan paparan dinamik dan statik ini berpotensi mengatasi masalah keyakinan keterlaluan yang mungkin wujud sekiranya sesuatu kandungan itu dipapar secara dinamik semata-mata, sebagaimana digariskan oleh Awan dan Stevens (2006).

Berbeza dengan ciri paparan berterusan seperti dalam strategi KB dan TK, maklumat bertali arus yang memasuki struktur memori pelajar memungkinkan berlaku keciciran maklumat berguna (Betrancourt, 2005). Perkara ini tidak membantu dalam proses pembinaan model mental yang sempurna berkaitan sesuatu topik yang dipelajari serta berkemungkinan menyumbang kepada kegagalan pembelajaran berkesan dalam tempoh masa yang singkat. Walaupun pelajar diberi 
kebebasan untuk berhenti dan memainkan animasi dalam strategi $\mathrm{KB}$, namun fitur ini dilihat tidak membantu pembelajaran berkesan berbanding sekiranya segmen itu ditentukan oleh pembangun perisian. Pelajar kemungkinan tidak mengetahui titik berhenti yang bermakna akibat topik yang dipelajari itu adalah sesuatu topik yang abstrak. Kajian lanjut yang melihat interaksi pelajar terhadap fitur kawalan dilihat dapat menjawab persoalan ini. Sementara itu, strategi TK pula dilihat bukanlah pilihan strategi yang baik untuk mempelajari topik-topik yang abstrak. Strategi ini dilihat tidak mampu memperuntukkan tempoh masa yang bersesuaian kepada pelajar dan menyebabkan fokus serta perhatian pelajar terjejas dan peranan animasi sebagai alat bantu mengajar berpotensi gagal (Spanjers et al., 2011; Moreno, 2007; Mayer 2010; Ahmad Zamzuri, 2007; Mayer et al., 2003; Torres \& Dwyer, 1991).

Sementara itu, implikasi kajian ini menunjukkan penggunaan koswer animasi bersegmen dengan strategi KPR dan KPL adalah yang terbaik berbanding strategi KP, KB dan TK. Dapatan ini menunjukkan faktor reka bentuk paparan animasi bersegmen yang disertakan dengan strategi kawalan pengguna yang bersesuaian berkemampuan mengatasi fenomena keciciran maklumat. Strategi KPR dan KPL didapati membantu dalam memperuntukkan masa yang bersesuaian bagi memori sensori pelajar untuk mengekstrak maklumat daripada animasi untuk diproses dalam memori jangka pendek yang agak terbatas sebelum didaftarkan ke dalam memori jangka panjang. Kedua-dua strategi ini juga didapati berupaya meningkatkan prestasi pencapaian pelajar.

\section{KESIMPULAN}

Berdasarkan dapatan-dapatan yang diperoleh daripada kajian, beberapa rumusan dan kesimpulan telah dibuat. Pada keseluruhannya, reka bentuk Strategi Kawalan Pengguna Rawak (KPR) dan Strategi Kawalan Pengguna Linear (KPL) telah memberi kesan yang signifikan terhadap prestasi ujian pos yang lebih baik berbanding Strategi Kawalan Program (KP), Strategi Kawalan Berterusan (KB) dan Tanpa Kawalan (TK). Fenomena ini adalah disebabkan oleh ciri reka bentuk paparan animasi yang diberi tempoh masa selama 15 saat untuk setiap paparan diamati sebelum bergerak atau digerakkan ke paparan animasi yang seterusnya. Tanpa peruntukan masa yang bersesuaian, pelajar tidak akan berupaya membina model mental 
yang sempurna bagi pembentukan skema baru dengan merangsang skema sedia ada dalam struktur memori (Garhart \& Hannafin, 1986). Strategi persembahan yang memperuntukkan lebih banyak masa berinteraksi dengan bahan instruksi, berpotensi menjadikan proses mendaftar jujukan maklumat dalam struktur memori jangka panjang lebih berkesan dan sempurna (Slater \& Dwyer, 1996). Animasi yang disegmenkan dengan fitur kawalan yang mengawal paparan segmen-segmen tersebut berbanding melihat keseluruhan paparan animasi secara berterusan secara pasif berpotensi menangani permasalahan ini (Boucheix \& Guignard 2005; Ahmad Zamzuri, 2007; Moreno, 2007; Mayer \& Moreno, 2003; Mayer \& Chandler, 2001). Sehubungan itu, rumusan dibuat bahawa membahagikan paparan animasi kepada segmen-segmen kecil yang bermakna dan dengan strategi kawalan pengguna untuk memapar segmen-segmen mengikut masa paparan yang bersesuaian, sama ada secara rawak atau linear didapati berupaya membantu meningkatkan prestasi pelajar.

\section{RUJUKAN}

Ahmad Zamzuri, M. A. (2013). Effects of Segmented-Animation in Projected Presentation Condition. Educational Technology \& Society, 16 (3), 234-245.

Ahmad Zamzuri, M. A., Rahani, W., Khairulanuar, S., \& Mohammad Zaffwan, I. (2013). Reading on the computer screen: Does font type has effects on web text readability? International Education Studies, 6(3), 26-35. doi:10.5539/ies. v6n3p26.

Ahmad Zamzuri, M. A., (2007). Kesan koswer strategi animasi pelbagai kawalan pengguna terhadap prestasi kognitif dan ketekalan pelajar. Tesis Doktor Falsafah (Tidak Diterbitkan). Pulau Pinang: Universiti Sains Malaysia.

Ainsworth, S. (2008). How do animations influence learning? In Robinson, D.H., \& Schraw, G. (Eds.), Current perspectives on cognition, learning, and instruction: Recent innovations in educational technology that facilitate student learning. (pp. 37-67). North Carolina: Information Age Publishing.

Alessi S. M., \& Trollip, S.R. (2001). Multimedia for learning: Methods and development (3rd ed.). Boston: Allyn \& Bacon. 
Aminordin C. L., Ng, K.T. \& Fong, S.F. (2004). Kesan paparan grafik dalam pembelajaran fenomena cuaca (Effects of graphic in learning weather phenomena). Proceedings of 17 th Educational Technology Convention, Malaysia. 249-255.

Astuty, M.S., \& Yuniar, C.S.W. (2013). Tingkat beban kerja mental masinis berdasarkan NASA-TLX (Task Load Index) di PT. KAI Daop.II Bandung, Jurnal Online Institut Teknologi Nasional, 1(1). Retrieved from http://ejurnal.itenas.ac.id/ index.php/rekaintegra/article/view/217/454.

Atkinson, R. C., \& Shiffrin, R. M. (1968). Human memory: A proposed system and its control processes. In Spence, K.W., Spence, J.T (Eds.). The psychology of learning and motivation, (2 $2^{\text {nd }}$ ed.), 89-195. New York: Academic Press.

Awan, R. N., \& Stevens, B. (2006). Static/animated diagrams and their effect on student's perceptions of conceptual understandings in Computer Aided Learning (CAL) environments. In McEwan, T., Gulliksen, J., \& Benyen, D. (Eds), People and computers XIX - The bigger picture (pp. 381-389). London, UK: Springer-Verlag.

Ayres, P., \& Paas, F. (2007). Can the cognitive load approach make instructional animations more effective? Applied Cognitive Psychology, 21(6), 811-820. doi:10.1002/acp.1351.

Ayres, P., Marcus, N., Chan, C., \& Qian, N. (2009). Learning hand manipulative tasks: When instructional animations are superior to equivalent static representations. Computers in Human Behavior, 25(2), 348-353. doi:10.1016/j.chb.2008.12.013.

Ayres, P. \& Paas, F. (2012). Cognitive load theory: New directions and challenges. Applied Cognitive Psychology, 26 (6), 827832. doi: $10.1002 /$ acp. 2882.

Betrancourt, M. (2005). The animation and interactivity principles in multimedia learning. In Mayer, R. E (Ed.). The Cambridge handbook of multimedia learning (pp. 287-29). New York, NY: Cambridge University Press.

Boucheix, J. M., \& Schneider, E. (2009). Static and animated presentations in learning dynamic mechanical systems. Learning and Instruction, 19(2), 112 - 127. doi :10.1016/j. learninstruc.2008.03.004.

Boucheix, J. M., \& Guignard, H. (2005). What animated illustrations conditions can improve technical document comprehension in young students? Format, signaling and control of the presentation. European Journal of Psychology of Education, 20(4), 369-388. doi:10.1007/BF03173563. 
Cairncross, S., \& Mannion, M. (2001). Interactive multimedia and learning: Realizing the benefits. Innovations in Education and Teaching International, 38(2), 156-64. doi:10.1080/14703290110035428.

Chung, J., \& Reigeluth, C. M. (1992). Instructional prescriptions for learner control. Educational Technology, 32(10), 14-20. Retrieved from http://dl.acm.org/citation.cfm?id=152086.

Clark, R. C., Nguyen, F., \& Sweller, J. (2011). Efficiency in learning: Evidence-based guidelines to manage cognitive load. New York: Wiley.

Eggemeier, F. T. (1988). Properties of workload assessment techniques. In P.A. Hancock \& N. Meshkati (Eds.), Human mental workload (pp. 41-62). Amsterdam: Elsevier.

Fong, S.F. (2001). Kesan animasi terhadap pembelajaran pengetahuan prosedur meiosis di kalangan pelajar pelbagai profil psikologi. Tesis Doktor Falsafah (Tidak Diterbitkan). Pulau Pinang: Universiti Sains Malaysia.

Fraenkel, J.R., \& Wallen, N.E., (1996), How to design and evaluate research. USA: Mc. Graw-Hill Inc.

Garhart, C., \& Hannafin, M. (1986). The accuracy of cognitive monitoring during computer based instruction. Journal of Computer Based Instruction, 13(3), 88-93. Retrieved from http://0-files.eric.ed.gov.opac.msmc.edu/fulltext/ED267768. pdf.

Hasler, B. S., Kersten, B., \& Sweller, J. (2007). Learner control, cognitive load and instructional animation. Applied Cognitive Psychology, 21(1), 713-729. doi:10.1002/acp.1345.

Hegarty, M. (2004). Dynamic visualization and learning: Getting to the difficult questions. Learning and Instruction, 14(3), 343351. doi:10.1016/j.learninstruc.2004.06.007.

Ivers, K.S., \& Barron, A. E. (1998). Multimedia projects in education: Designing, producing and assessing. Westport, CT: Libraries Unlimited.

Ivers, K.S.,\& Barron, A. E. (2002). Multimedia projects in education: Designing, producing and assessing (2nd ed.). Westport, CT: Libraries Unlimited.

Ivers, K.S.,\& Barron, A. E. (2006). Multimedia projects in education: Designing, producing and assessing (3rd ed.). Westport, CT: Libraries Unlimited. 
Jun-Xia, G. (2007). Action research: The application of cognitive load theory to reading teaching. Sino-US English Teaching, 4(4), 19-23. Retrieved from https://www.researchgate.net/ publication/237584679_Action_Research_The_Application_ of_Cognitive_Load_Theory_to_Reading_Teaching.

Kemp, J. E. , \& Smellie, D.C. (1997). Perancangan penerbitan dan penggunaan media pengajaran (6th ed.). Skudai, JB: Universiti Teknologi Malaysia.

Kettanurak, V.N., Ramamurthy, K., \& Haseman, D. (2001). User attitude as a mediator of learning performance improvement in an interactive multimedia environment: an empirical investigation of the degree of interactivity and learning styles. International Journal of Human-Computer Studies, 54(4), 541-583. doi: 10.1006/ijhc.2001.0457.

Kubiszyn, T., \& Borich, G., (2000). Educational testing and measurement: Classroom application and practice (6th ed.). New York: John Wiley \&Sons.

Lai, S. L., (2001). Controlling the display of animation for better understanding. Journal of Research on Technology in Education, 33(5). Retrieved from http://www.iste.org/ jrte/33/5/lai.html.

Li, X., \& Soh, L. (2003). A literature review on learner control strategies in software tutoring system. Retrieved from http:// digitalcommons.unl.edu/cgi/viewcontent.cgi?article $=1074 \&$ context=csetechreports .

Lin, H., \& Dwyer, F.M. (2010). The effect of static and animated visualization: A perspective of instructional effectiveness and efficiency. Educational Technology Research and Development, 58(2),155-174.doi: 10.1007/s11423-009-9133-x.

Lin, C.L., \& Dwyer, F. M. (2004). Effect of varied animated enhancement strategies in facilitating achievement of different educational objectives. International Journal of Instructional Media, 31(2), 185-199.

Liu, M., Jones, C., \& Hemstreet, S. (1998). Interactive multimedia design and production processes. Journal of Research on Computing in Education, 30(3), 254-281. Retrieved from http://faculty.mercer.edu/codone_s/tco325/design_production. pdf.

Lowe, R. K. (2004). Interrogation of a dynamic visualization during learning. Learning and Instruction, 14(3), 257-274. doi: 10.1016/j.learninstruc.2004.06.003. 
Lowe, R.K. (2003). Animation and learning: selective processing of information in dynamic graphics. Learning and Instruction, 13(2), 157-176. doi: 10.1016/S0959-4752(02)00018-X.

Mohd Majid, K. (2009). Kaedah penyelidikan pendidikan. Kuala Lumpur: DBP

Mayer, R. E. (2005). Cognitive theory of multimedia learning. In Mayer, R. E. (Ed.). The Cambridge handbook of multimedia learning (pp. 31-48). New York, NY: Cambridge University Press.

Mayer, R.E., \& Moreno, R. (2003). Nine ways to reduce cognitive load in multimedia learning. Educational Psychologist, 38(1), 43-52. doi: 10.1207/S15326985EP3801_6.

Mayer, R. E., \& Chandler, P. (2001). When learning is just a click away: does simple user interaction foster deeper understanding of multimedia messages? Journal of Educational Psychology, 93(2),390-397. doi:10.1037/0022-0663.93.2.390.

Moreno, R. (2007). Optimising learning from animations by minimizing cognitive load: Cognitive and affective consequences of signalling and segmentation methods. Applied Cognitive Psychology, 21(6), 765-781. doi: 10.1002/ acp.1348.

Mireille, B., \& Cyrill, R. (2007). Building dynamic mental models from animation: Effect of user control on exploration behaviours. Proceedings of the 12th EARLIbiennal Conference on Research and Learning and Instruction,188-192. Retrieved from http://tecfa.unige.ch/perso/mireille/papers/Betrancourt_ RebetezEARLI07.pdf.

Norman, D. A. (1982). Learning and memory. New York, NY: WH Freeman \& Co.

Pallant, J. (2007). SPSS survival manual: A step-by-step guide to data analysis using SPSS for Windows (Version 15) (3rd ed). Crows Nest, NSW: Allen \& Unwin.

Rubio, S., Díaz, E., Martín, J., \& Puente, J. M. (2004). Evaluation of subjective mental workload: A comparison of SWAT, NASATLX, and workload profile methods. Applied Psychology: An International Review, 53(1), 61-86. doi: 10.1111/j.14640597.2004.00161.x.

Schnackenberg, H.L., \& Sullivan, H.J. (2000). Learner control over full and lean computer based instruction under differing ability levels. Educationa Technology Research and Development, 48(2), 19-35. Retrieved from http://link.springer.com/article/ 10.1007\%2FBF02313399\#page-1. 
Slater, R.B., \& Dwyer, F. (1996). The effect of varied interactive questioning strategies in complementing visualized instruction. International Journal of Instructional Media, 23(3), 273-280. Retrieved from http://eric.ed.gov/?id=EJ569022.

Sperling, R. A., Seyedmonir, M., Aleksic, M., \& Meadows, G. (2003). Animations as learning tools in authentic science materials. International Journal of Instructional Media, 30(2), 213-222. Retrieved from http://dheise.andrews.edu/ Content/leadership/comps/1a/Animation.pdf

Spanjers, I. A. E., Wouters, P., van Gog, T., \& Van Merrienboer, J. J. G. (2011). An expertise reversal effect of segmentation in learning from animated worked-out examples. Computers in Human Behavior, 27(1), 46-52. doi: 10.1016/j. chb.2010.05.011

Spanjers, I. A., van Gog, T., \& van Merriënboer, J. J. (2010). A theoretical analysis of how segmentation of dynamic visualizations optimizes students' learning. Educational Psychology Review, 22(4), 411-423. doi: 10.1007/s10648010-9135-6

Sweller, J. (2004). Instructional design consequences of an analogy between evolution by natural selection and human cognitive architecture. Instructional Science, 32(1-2), 9-31. doi:10.1023/B:TRUC.0000021808.72598.4d.

Tabbers, H., \& de Koeijer, B. (2010). Learner control in animated multimedia instructions. Instructional Science, 38(5), 441453. doi: 10.1007/s11251-009-9119-4.

Torres, J., \& Dwyer, F. (1991). The effect of time in instructional effectiveness of varied enhancement strategies. International Journal of Instructional Media, 8(4), 2-8.

Tversky, B., Morrison, J.B., \& Betrancourt, M. (2002). Animation: Can it facilitate? International Journal of Human Computer Studies, 57(4), 247-262. doi: 10.1006/ijhc.2002.1017.

van Oostendorp, H., Beijersbergen, M.J., \& Solaimani, S. (2008). Conditions for learning from animations. Proceedings of the 8th International Conference on Learning Science,2(1), 438-445. Retrieved from http://dl.acm.org/citation.cfm?id=1 $599926 \& \mathrm{dl}=\mathrm{ACM} \& \mathrm{coll}=\mathrm{DL} \& \mathrm{CFID}=614080807 \& \mathrm{CFTOK}$ $\mathrm{EN}=95575446$.

Wilson, F., \& Dwyer, F. M. (2001). Effect of time and level of visual enhancements in facilitating student achievement of different educational objectives. International Journal of Instructional Media, 28 (2), 159-167. 
Weir, G.R.S, \& Heeps, S. (2003). Getting the message across: Ten principles for web animation. Proceedings of the 7th IASTED International Conference on Internet and Multimedia and Applications, 121-126. Retrieved from http://citeseerx.ist. psu.edu/viewdoc/download?doi=10.1.1.185.135\&rep=rep1\& type $=$ pdf.

Windell, D., \& Wiebe, E. N. (2007). Measuring cognitive load in multimedia instruction: A comparison of two instruments. Annual meeting of the American Educational Research Association. Retrieved from http://www4.ncsu.edu/ wiebe/ articles/Windell-AERA-2007.pdf.

Wong, A., Leahy, W., Marcus, N., \& Sweller, J. (2012). Cognitive load theory, the transient information effect and e-learning. Learning and Instruction, 22(6), 449-457. doi: 10.1016/j.learninstruc.2012.05.004.

Wouters, P., Paas, F., \& van Merriënboer, J. J. G. (2008). How to optimize learning from animated models: a review of guidelines based on cognitive load. Review of Educational Research, 78 (3), 645-675. doi:10.3102/0034654308320320.

Xiao, Y. M., Wang, Z. M., Wang, M. Z., \& Lan, Y. J. (2005). The appraisal of reliability and validity of subjective workload assessment technique and NASA-task load index. Chinese Journal of Industrial Hygiene and Occupational Diseases, 23(3), 178. Retrieved from http://www.ncbi.nlm. nih.gov/pubmed/16124892. 